\title{
Diogo Mainardi e uma(sua) nacionalidade outra
}

\author{
José Luiz Foureaux de Souza Júnior
}

\begin{abstract}
Resumo: O presente artigo procura desenvolver uma leitura do romance de Diogo Mainardi, Contra nação, considerando a possibilidade de enxergar no texto referências a um discurso de desconstrução da idéia de nação. A leitura depreende do texto uma possível discussão da dicotomia moderno $\mathrm{X}$ pós-moderno, dado que a paródia e a ironia permeiam o discurso ficcional, fazendo emergir do texto referências aparentemente desvinculadas de sua leitura.
\end{abstract}

Palavras-chave: leitura; ficcionalidade; Diogo Mainardi, narrativa; recepção

\begin{abstract}
This paper intends to develop an innovative reading of Diogo Mainardi's novel Contra a nação (Against nation). I consider the possibility of finding in Mainardi's text references to a discourse of deconstruction of the idea of nation. This reading finds in the text a possible discussion of the modern $\mathrm{X}$ postmodern dichotomy, given that parody and irony permeate the fictional discourse, which makes references that are apparently disconnected of its reading surface from the text.
\end{abstract}

Keywords: reading; fictionality; Diogo Mainardi; narrative; reception

Quanto a tudo mais podemos dissimular; fazer, como filósofos, belos discursos de forma excelente; conservar a nossa serenidade em face de acidentes que nos atinjam superficialmente. Mas na última cena, a que se representa entre nós e a morte, não há como fingir, é preciso explicar-se com precisão em linguagem clara e mostrar o que há de autêntico e bom no fundo de nós mesmos: "então a necessidade arranca-nos palavras sinceras, então cai a máscara e fica o homem". [Lucrécio]

Michel de Montaigne, Ensaios

Na discussão sobre Realismo e Narrativa caberia um elenco bastante numeroso de variáveis e critérios que poderiam ser objeto de um tratado. No espaço de um artigo e/ou de um ensaio, é necessário fazer recortes, deixar implícitas algumas pistas. Sobretudo, na limitação que se impõe quer pelo tempo, quer pelo espaço, quer por outro critério, é necessário sempre uma introdução. Pois aqui está ela. Obviamente, seu papel aqui é tentar orientar os passos do leitor para o que segue, em forma de artigo.

Se fosse necessário, eu discorreria sobre o Realismo, entendido, em primeiro lugar, como uma estética, cronológica e culturalmente "localizada". Também não é bem o caso. No entanto, a natureza da narrativa de Diogo Mainardi, aqui tomada como corpus de sustento de minha argumentação, faz suspeitar do fato de que o espírito realista, consignado pela estética

\footnotetext{
* Ph.D, Doutor em Literatura Comparada, Professor Adjunto de Literatura Luso-Brasileira, na Universidade Federal de Ouro Preto, Leitor de Português na Universidade de Zagreb (Croácia).
} 
anteriormente referida, ainda faz prevalecer algumas de suas idiossincrasias. Como poderá ser constatado (ou não, isso depende do leitor!) o romance em questão faz repensar a categoria do "retrato", do desenho de uma realidade,como prática discursiva que se apóis na descrição, como instrumento de linguagem. O Realismo diz, então, presente. No entanto, a prática ficcional do autor estudado não permite circunscrever seu romance a fronteiras tão estreitas. Vale, então, o aviso prévio de que não se trata de um romance realista, comme il faut, mas de uma narrativa cujo realismo não pode ser descartado. Afirmo isso porque, na perspectiva da ironia imposta pelo discurso anárquico do narrador, algo de insuspeitado faz pensar na importância do realismo como uma chave de leitura. Mais uma vez, cabe ao leitor do texto a palavra final.

Isto posto, cabe ainda observar que na ilação textual que se pode articular a partir das categorias "realismo" e "narrativa" são tantas que o recorte é quase fatal. E o adjetivo aqui recobre-se de um sentido pejorativo que, em nada e por nada, desmerece a importância do romance aqui compulsado. Sua importância se deve, antes de mais, pela revisitação que faz a certos procedimentos ditos "modernistas" - no que isto tem de doutrinário e pedagógico uma vez que faz lembrar certas passagens de Oswald de Andrade, no mínimo, aquele de Memórias sentimentais de João Miramar, para ficar com um só exemplo!. A contrapartida da História, em que, em sombra, aparece na imagem suscitada do Marechal Rondon e do caminho que este determinou em terras brasileiras, é outra variável a ser destacada. Importa fazê-lo dado que, quando se fala em Realismo, entre outras coisas, suscita-se o questionamento de sua verve "objetiva", como uma instrumentalidade cara, tanto à Estética referida, quanto à prática historiográfica. Mais uma vez, é na sombra de referências implícitas no texto ficcional que se vai encontrar respaldo para afirmações como esta.

De todo modo, quando se afirma que o narrador pode não mais estar presente no horizonte de expectativas, tanto do leitor, quanto da crítica - em que pesem os severos questionamentos que tal idéia suscita - a faculdade de intercambiar experiências, alimentada pela leitura, sai perdendo. E esta perda leva junto à possibilidade de se revisitar conceitos e procedimentos, tais como os de Realismo e Narrativa, para auferir abordagens refrescantes de um cânone obrigatoriamente reconstruível, em sua sequiência e permanência cronológica. Chega a assustar, então, a idéia de no fundo das gavetas espalhadas por "departamentos", em todas as institucionais que o planeta Terra conhece, a narração é uma forma que se perde e que a experiência está esquecida como quinquilharias no sótão poeirento. Por isso, levar em consideração o Realismo, pensado como uma categoria, nos moldes em que o foi há mais ou menos 70 anos nos nossos dias, não pode se deixar abater pela estapafúrdia idéia de que a 
“informação" está acima de qualquer coisa. Há que manter acesa a verdade pulsante de que as vivências e os choques da vida moderna permitem, sempre, a construção da experiência. De outro lado, o conhecimento livresco não destrói a sabedoria vivida, mas a alimenta. Por fim, a palavra não perdeu sua voz própria. Disto é prova irrefutável o romance de Diogo Mainardi, Contra o Brasil, texto em que se pode fazer duas de tantas outras "experiências" de leitura: o redimensionamento da discussão acerca da ilação entre Realismo e Narrativa, por um lado; a revisitação dos cânones historiográficos da Literatura Brasileira, pela contramão de seu próprio encaminhamento, por outro. É o que, aqui se pretende... ensaiar!

Estar fora de lugar supõe a existência de um lugar. A aparente obviedade dessa afirmação esconde um sofisma insondável, verdadeiro desafio filosófico. O discurso tem tentado elaborar as partes constitutivas desse sofisma para dar-lhe feição racional e, com isso, tentar dirimir a dúvida e a ignorância que permanecem. Esta é uma direção possível para pensar o tema desse artigo. Ele fala de um Brasil "literário", um Brasil ficcional que se assemelha muito ao real. Um Brasil da História, revisitado por um escritor de verve irônica, sarcástica quase amarga, à luz de Montaigne, que aparece em epígrafe. Fica, então, a pergunta: o que é o Brasil? Se continuar nessa linha de raciocínio, chego ao ponto central de minha interferência: o lugar de Diogo Mainardi na Literatura Brasileira ou, em outras palavras, como falar desse brasileiro fora do Brasil.

$\mathrm{Na}$ onda dos estudos culturais, cabe aqui uma digressão provocativa. Trata-se de considerar que a Teoria da Literatura - instrumento que auxilia na leitura da anunciada contra-nacionalidade aqui - ocupa uma espécie de entrelugar, um intervalo - na esteira do que propõe João Alexandre Barbosa - que faz com que as suas "verdades", de resto, como todas as outras, sejam sempre objeto de uma outra visada, uma outra leitura. Assim é que a digressão cumpre aqui o papel de instaurar esta suspensão, esse intervalo, para que eu possa provocar o leitor.

Para falar desse entrelugar, que a Teoria da Literatura ocupa hoje, é necessário pensar sobre a consistência (ou não!) dos famigerados "estudos culturais". Na verdade, a expressão já aparecia no discurso crítico de Fredric Jameson, ao final dos anos oitenta, mas por aqui tomou fôlego um pouco mais tarde, acompanhando uma discutível crise dos estudos literários. $\mathrm{O}$ adjetivo se justifica, uma vez que os estudos literários, em sua História, sempre se sustentaram por uma crise "essencial" - muito bem perseguida e teorizada pelos formalistas russos. Essa afirmação cumpre seu papel de justificar a constatação de que sem crise, a Teoria da Literatura não teria chegado onde chegou. 
Por outro lado, utilizar o argumento de que o texto literário já não ocupa hoje o lugar que ocupava, não leva a lugar nenhum. Num momento de "globalização" - seja lá o que isso venha a significar! - em que os meios de comunicação estão a cada minuto mais sofisticados, o lugar ocupado pelo livro é matéria de uma reflexão específica que, de uma maneira ou de outra, vai seguir os desdobramentos possíveis da própria Teoria da Literatura.

É pertinente admitir, em todo caso, que haja um alargamento do espectro de influência e/ou de abrangência daquilo que genericamente vinha se chamando de estudos literários. Talvez por força da diversificação do conceito de cultura e de um exacerbado espírito pragmático, que alimenta o isolamento e a individualidade, abolindo limites e diferenças, criando uma zona ambígua de ilimitada extensão e inominada identidade, não seja mais possível pensar a Literatura como era pensada até o século XX. Até esse ponto eu posso concordar. Não é possível, a partir desse argumento, ditar a morte dos estudos literários, por força da indefinibilidade de seu objeto. Ora, essa mesma indefinibilidade é que fez com que a Teoria da Literatura chegasse aonde chegou, repito. Do contrário, não haveria a possibilidade de diversificação da abordagem deste "fenômeno", a Literatura. Talvez a institucionalização da Literatura, fazendo com que "disciplinas" sejam criadas e se consolidem no cenário universitário, seja a principal causa de uma confusão que elege os estudos culturais como um substituto adequado, eficaz e à altura das necessidades do momento presente. Ledo engano! Tal equívoco tem imperado como um elemento de redução dos estudos literários a uma universalização, sempre e diuturnamente, combatida, aparentemente fora da demanda legitimadora dos estudos culturais.

A irredutibilidade é hoje um tema que nomeia o jogo que se estabelece em debates ou séries de debates que envolvem a relativa substituição de aparato tradicional de estudos literários pelos estudos culturais, na reflexão transnacional sobre a cultura. Não estou de acordo com a expressão "substituição", mas seu uso aqui é apenas indicativo de um sintoma (quase institucionalizado) que eu não posso deixar de levar em conta. Esses debates envolvem ainda o peso das correntes intelectuais que fluem unilateralmente do discurso universitário. Digo unilateralmente porque, na verdade, a "base" teórica é de matiz norte-americano, o mesmo acontecendo com a tendência substitutiva dos estudos culturais, principalmente em sua "adaptação" equivocada em solo brasileiro. Nada disso, no entanto, se faz suficiente para a eleição dos estudos culturais como um "substituto", uma vez que não há o que substituir!

As condições desse movimento de redução discursiva de modelos, tidos e havidos como autônomos, de pensar a cultura, mudaram no decorrer das últimas décadas - a análise dos manuais de Teoria da Literatura é um exemplo demonstrativo disso, sem a menor dúvida. 
O que ainda podia ser levado em conta, enquanto permanência, constância, é uma tendência de cruzamento entre as pulsões norte-americanas e as forças centrípetas de um desejado (ainda que equivocado) universalismo científico. Em outras palavras, não há como continuar sustentando o discurso identitário, tomado sempre de modo paradigmático, como instrumento de afirmação de uma desejada sintonia entre Histórias específicas e epistemologias gerais, e vice-versa. Assim, a contribuição francesa, espanhola, italiana e argentina, por exemplo, vão ocupar um lugar importante nos estudos literários, principalmente se tomadas as balizas aqui implícitas.

A mudança não se deve apenas ao fato de que o próprio conceito de uma "epistemologia geral" vem sendo consistentemente criticado. Deve-se também ao fato de que, ao se inverter a definição freudiana de melancolia, toda vez que se busca refletir sobre a especificidade histórica à sombra do sujeito que reflete sempre, já se projeta sobre o objeto ela reflexão. O sujeito permanece, sempre e mais, indefinível a priori, ele vai sempre se constituir num espaço límbico de discurso que, a cada passo, toma uma configuração diferente. Assim, como o desaparecimento de qualquer mundo absolutamente "real" acaba por destruir a possibilidade de se pensar sobre seu aparecimento, o fracasso da certeza epistêmica é inevitável. Ou seja, a Teoria da Literatura vive de/em uma certa precariedade de experiência: o sujeito - autor, leitor, crítico, teórico - está, existe e age sempre sob a égide da dissolução de um objeto "próprio", específico.

Num primeiro momento, houve a hegemonia da antiga Filologia. Um instrumento para a universidade moderna refletir sobre o social a partir do legado cultural da comunidade nacional. Seu estatuto foi mantido assim pelo aparato literário, que excluiu ou subordinou a atenção dada a outros elementos simbólicos, também capazes de iluminar os processos de constituição cultural. Nessa perspectiva, é necessário pensar os estudos culturais, a que de modo apressado e com poucos matizes se outorga uma suposta genealogia britânico-norteamericana, não são reconhecidos por seus críticos como uma espécie de retorno às fontes filológicas. Assim, é possível criticá-los por se originarem de uma vontade cega ou oblíqua de negar a literatura, entendida como promessa de autonomia estética e teórica.

Diz-se que os estudos culturais politizam tudo e, portanto nada, sem atentar para a preservação dos valores propriamente estéticos que serviram de base para a possibilidade auto-reprodutora do intelectual humanista desde o Romantismo. É necessário, investigar qual é o estatuto da estética na reflexão contemporânea, por um lado; e, por outro, se a estética pode hoje funcionar como uma forma paradoxal de abertura para algum dado exterior em relação à História ou ao social, em relação aos quais a Teoria da Literatura poderia perseguir 
seu desejo de verdade, negando, sempre e mais, uma tendência à fetichização do real - nos moldes em que as "correntes" mais tradicionais demonstraram, em seu desenvolvimento.

O que está em jogo na pseudodicotomia estudos literários/estudos culturais não é outra coisa senão a peculiaridade do exercício teórico no âmbito das Ciências Humanas. Não se pode negar que nenhum dos dois campos em disputa pode monopolizar a atenção de quem se dedica aos exercícios teóricos, principalmente no que diz respeito à literatura. No entanto, a função desses exercícios é, exatamente, discutir as bases para que essa mesma dicotomia deixe de ocupar um lugar tão destacado, cedendo espaço para questões mais complexas, diversificadas e atraentes, como a representada pelo olhar homoerótico, dado que ele vai dinamizar a leitura do "texto cultural".

O perímetro de ação que os estudos culturais desenham não pode ser reduzido a um retorno ingênuo às raízes clássicas, isto é, românticas, da Filologia. Ao mesmo tempo, essa redução não se aplica aos estudos literários, como uma forma de desautorizá-los em sua consistência, necessitado que fica de uma substituição urgente e definitiva. Existe uma atividade político-intelectual que deve ser compreendida como uma espécie de desenvolvimento de uma relação crítica com o presente. A esta se dá o nome genérico de política acadêmica; no campo das Ciências Humanas - e, mais especificamente, no que se refere à legitimidade de ações da Teoria da Literatura, em busca de novos horizontes para as suas próprias expectativas.

Disso resulta que a atividade teórica, por princípio, não pode mais ser mantida com base na insistência em modalidades de discurso cultural que passaram a fazer parte de um "arquivo" documental e que tiveram sua pertinência e produtividade crítica praticamente esgotadas. Isso não se refere apenas aos estudos literários, mas, do mesmo modo, aos estudos culturais: a referência aqui está intimamente relacionada ao aparato que pretende estudá-la, ao discurso que se faz porta-voz de uma legitimidade que não "existe".

A tradição literária não tem feito outra coisa a não ser investigar a especificidade de uma teorização a partir de conceitos já batidos de identidade e diferença - o que ficará explicitado no levantamento de lacunas apresentadas pelos/nos manuais de Teoria da Literatura. $\mathrm{Na}$ verdade, essa reflexão compartilhou de teorias construtivistas de modo marginal. Estudos culturais e estudos literários são, ainda que exista quem negue, manifestações discursivas que teórica e criticamente estão sempre revisitando suas "bases". Isso se dá sem que sua pertinência e relevância sofram qualquer tipo de desvalorização. O que se conhece por "correntes" na/da Teoria da Literatura podem até ser assim consideradas, mas os conceitos de identidade e diferença, caros a um certo momento dos estudos literários, 
continuam a encontrar vida nova, ainda que precária, no espaço dos estudos culturais - e não poderia ser de outra forma. Outro fato é o de que grande parte dos trabalhos dos estudos culturais consiste apenas em reproduzir e transplantar para novos textos velhas categorias: a questão permanece "comicamente" a mesma. É claro que se ganha algo quando os critérios de inclusão de possibilidades teórico-metodológicas para um campo de conhecimento qualquer se ampliam. Nesse sentido, sou levado a concordar com Alberto Moreiras, quando afirma:

É certo, e contém a verdade da tautologia, que se ganha algo ao se ampliar os critérios de inclusão e ao tornar possível, para um acadêmico literário, ler o texto cinematográfico ou o texto dos novos movimentos sociais, ao passo que antes não se permitia ler mais que o texto ensaístico, novelístico ou poético. Nos estudos culturais dá-se um retorno à fonte filológica, pois a filologia procurava explorar a especificidade cultural a partir de um amplo repertório de linhas discursivas. Também é tautologicamente verdadeiro que se perde algo quando aqueles que lêem tais textos o fazem a partir de um certo enfraquecimento de sua capacidade técnica. Sua capacidade de leitura é, em princípio, enfraquecida porque leitores treinados para uma atenção exaustiva ao literário não conseguem simplesmente transferir sua atenção para o nãoliterário e passar a produzir resultados de tal esforço. Mas não se deve pensar que a história da leitura é estática, e que instrumentos adequados ao tipo de leitura que é pertinente à ampliação do espaço textual não serão em breve criados. Todavia, o que é mais certo, e também mais interessante, e não tautológico, é concluir que, se aceitamos uma análise tão simples como sendo correta, então os estudos culturais, da perspectiva literária, estão hoje muito longe de terem criado um novo paradigma para a reflexão latino-americanista.

(MOREIRAS, 2001, p. 15)

O autor se refere a um contexto localizado, o da América Latina. Sua argumentação se encaminha para uma defesa, cada vez mais acirrada, dos Estudos Culturais, como um substitutivo adequado para os Estudos Literários, no mesmo contexto. No entanto, ele fala das contribuições possíveis para se procurar as saídas, igualmente possíveis, da interlocução entre os dois campos concorrentes. Assim, sua visada aponta para o caráter interdisciplinar que deve imperar sobre todas as diferenças, fazendo com que os impasses que se criam, transformem-se em matéria de especulação teórica; no sentido de dinamizar, sempre e mais, os estudos voltados para a Literatura, para a Cultura.

Não sei, então, porque denegar o fato de que os Estudos Culturais são, até certo ponto, a expansão do mesmo, "mais da mesma coisa", como diz o próprio Moreiras. Determinar uma prevalência entre essas duas "denominações", muito antes de legitimar essa ou aquela opção "política", é reafirmar um dispensável anacronismo que faz do diferente, o mesmo. Porque manter essa "disputa" entre os dois campos, se eles se interpenetram e mantêm, ainda que muita gente não aceite, relações intrínsecas de auto-reflexividade mútua? Uma outra maneira de se fazer a mesma pergunta pode ser:

[...] se o antigo aparato critico literário e o novo aparato culturalista lidam com o mesmo conceito de razão crítica, e se tal conceito está circunscrito à determinação, avaliação e defesa do que é propriamente latino-americano, ou intralatino-americano, na modernidade alternativa latino-americana específica, e, ainda, se o conceito de razão crítica utilizado por ambos os 
participantes da disputa não consegue ir além da afirmação de um espaço identitário de resistência, seja do ponto de vista continental, nacional ou intranacional, então de que forma está em jogo nesses debates qualquer conceito real de crítica?

(MOREIRAS, 2001, p. 16)

As perguntas ficam em aberto. Sua resposta pode ser encontrada com os mais diversos encaminhamentos do raciocínio. Aqui, elas apontam para um fato que interessa, antes de mais nada: o real e consistente trabalho teórico tem que estar além das limitações políticas, ainda que estas sejam reconhecidas. Em outras palavras, qualquer vinculação ideológica que leve a respostas unilaterais para qualquer uma dessas perguntas, está fadada a ser responsabilizada pela falência da crítica e da teoria, enquanto procedimentos discursivos que se querem críticos e abertos aos desafios de inerentes à sua própria prática.

A falácia do discurso de defesa dos Estudos Culturais transparece na própria argumentação e, apenas assim, tenta redimir o discurso da Literatura. Isso constitui uma insuficiência que se revela apenas se for denegada a herança/missão humanística do exercício crítico voltado para a Literatura. A questão de fundo é ética e não conjuntural. O substantivo está sendo substituído pelo circunstancial. Se os estudos literários perderam sua "função", porque continuar afirmando sua desimportância com tanta veemência? O que se vê é uma fuga do ponto nevrálgico (humanismo), em nome de uma redução conceitual, da ordem do capitalismo, das relações que passam a ser "valorizadas", apenas e somente, enquanto superficialidades transitórias.

Isto posto, a idéia de lugar deixa de ser um vetor definitivo e inescapável, dado que sua constituição discursiva o coloca numa esfera de plausibilidade interpretativa. De mais a mais, dizer que a nacionalidade de uma literatura pode ser/seria identificada por sua redução a uma língua nacional, mediatizada por um autor nacional, é por si só questionável. Suficientemente questionável, para não ser considerada como ponto de partida seguro. Neste sentido, não é abusado considerar a dificuldade de compreender o fenômeno da literatura da Índia, por exemplo, apenas reconhecida mundialmente (em certa medida) quando publicada em Língua Inglesa. O que é, então, a literatura da Índia? Então, todos os escritores indianos estão fora de seu país.

Dessa maneira, os critérios tradicionalmente utilizados para identificar a "nacionalidade" de uma literatura mostram-se insuficientes. Imagine-se um brasileiro, que vive na Europa, escrevendo em português sobre o Brasil. Seria esse um exemplo de Literatura Brasileira? Como no caso da Índia, ainda que por caminhos diferentes, essa questão se impõe: estar fora de um território não pode ser um critério excludente. Em alguns casos, como acontece aqui, essa "localização" é exatamente amola mestra de um exercício de autocrítica 
saudável, mais que necessário. A série de indagações não pára por aí, mas a utilização que delas faço sim. Quero deter-me, especificamente, numa brevíssima apresentação desse tópico - estar fora de algum lugar -, tomando como ponto de partida o "romance" Contra o Brasil, de Diogo Mainardi. O título vem ao encontro de minhas primeiras colocações, pois estabelece uma expectativa no mínimo curiosa: o que está contra o Brasil? Ou ainda: quem está, ou é, contra o Brasil? No entanto, ao final da leitura, o que se percebe é que não há nada "contra" o Brasil, mas contra um certo Brasil, ou um Brasil sonhado, inventado, "achado" como diz a carta de Caminha. Há que se ressaltar que a palavra "contra", enquanto elemento composicional, guarda, para além do significado de oposição direta, de negação, um sentido outro de "estar diante de", o que não deixa de ser uma posição oposta, mas reveladora de uma nuance, ao mesmo tempo delicada e cavilosa, de estar "reconhecendo" alguma coisa. A língua tem dessas sutilezas...

De cara, percebe-se um intrincado trabalho de pesquisa, numa espécie de releitura de arquivos e documentos que narram a História do Brasil, principalmente a História contada pelos estrangeiros que aqui estiveram a partir do século XVI. Começando com uma obsessiva fixação em Claude Lévi-Strauss, o autor passa por antropólogos, sanitaristas, médicos, sociólogos, militares, historiadores, filósofos, músicos, poetas, comerciantes, renegados, pastores evangélicos, presidentes republicanos (ou democratas, eu não sei!) etc. Uma pequena amostra de tão variada plêiade é a seguinte lista de nomes: Michel de Montaigne, Roger Bastide, Charles Darwin, Spix e Martius, Prosper Mérimée, Marechal Rondon, Giuseppe Ungaretti, Kaspar Bele, Simão de Vasconcelos, André Thevet, Thomas Hardy, Conde de Gobineau, Jean-Paul Sartre, Theodore Roosevelt, Claude d'Abbeville, Auguste de Saint Hilaire, G.K. Chesterton, Guy de Maupassant, Albert Camus, Elisabeth Bishop e P. David Price, entre muitos outros. Uma galeria de personagens que faz companhia a alguns nomes das letras nacionais como José de Anchieta, Mário de Andrade, Castro Alves, José de Alencar e Gonçalves Dias. Estranha mistura, mais estranho ainda o resultado. Visitantes reais ou meramente referências textuais, as “citações' do narrador compõem um intrincado tecido de vozes que nenhuma harmonia alcançam, a não ser por um ponto: o Brasil é seu objeto. Qual Macunaíma pós-moderno (se quiserem alguns), o protagonista desfaz e refaz os discursos, às vezes, desencontrados, mas sempre direcionados para o mesmo ponto: o Brasil.

Propositadamente, o autor constrói sua narrativa a partir de citações de todos aqueles que foram objeto de sua (igualmente) obsessiva busca. O protagonista, Pimenta Bueno, é um exímio manipulador de palavras alheias, fazendo confundir os analistas do discurso quando se debruçam sobre a questão da alteridade. Não há etnografia capaz de deslindar essa ficção que 
se quer, ao mesmo tempo, crítica e safada, no sentido mais popular do termo. Safada sim, pois ao mesmo tempo em que destrói alguns dos mitos "nacionalizantes" de nossa cultura, a narrativa de Mainardi reforça os traços dessa mesma nacionalidade, agora robustecida por sua autocrítica. Esse é o exercício do protagonista, um constante olhar sobre si mesmo, tirando o melhor de cada situação, sempre, é claro, em proveito próprio. Uma espécie de eternização da famigerada Lei de Gerson: “você tem que levar vantagem em tudo, certo!?”. O sotaque malandramente carioca, que acompanha o autor dessa máxima da ética social de um certo Brasil, pode ser ouvida da boca de personagens globalizados de programas televisivos como Big Brother Brasil e Casa dos artistas, por exemplo.

A capa da edição aqui compulsada é reveladora de todas essas caraterísticas. Ela mostra um grupo de escoteiros (o que já é sintomático!) portando a bandeira do Brasil, em meio a uma caminhada - aparentemente de conquista de território - numa clareira. Uma associação com a famosa tela de De Chirico não pode ser aqui esquecida, pois revela uma interlocução com o modus operandi do Romantismo que tanto esforçou-se na direção afirmativa das nacionalidades. As cores predominantes são as mesmas da bandeira nacional, com exceção do nome do autor que vem em tarja vermelha. Simbolicamente revolucionária, essa cor aponta para o caráter perverso da narrativa que vai se ler, sob a pena desse brasileiro que vê sua pátria de fora, no mínimo, em dois sentidos: física e culturalmente. Mainardi reescreve a História de um certo Brasil, ou melhor, conta uma história de redescoberta do Brasil. Uma história literária, porque escrita, por um lado; uma história da literatura, por outro, uma vez que todas as referências podem ser relacionadas sob esse paradigma. De qualquer maneira, uma história (vista) contada pelo avesso, de fora para dentro. O romance pode ser lido como uma resposta a Tristes trópicos, de Lévi-Strauss: um exercício antropofágico com a personagem oculta obsessivamente perseguida pelo protagonista.

Em se tratando de exercício antropofágico, posso remeter meu raciocínio à idéia de uma poética do descentramento, para utilizar os termos de Affonso Romano de Sant'Anna, ao analisar as linguagens do Modernismo, em ensaio intitulado "Modernismo: as poéticas do centramento e do descentramento". Nesse trabalho, o crítico e poeta carioca desvela-se na análise do pressuposto de que existe, no fundo, um entrecruzamento de linguagens no Modernismo, o que funciona como solo comum para as diversas manifestações poéticas concernentes aos desdobramentos estéticos da Semana de 22, principalmente no que diz respeito à poesia. Ainda que não se trate do mesmo "gênero" literário, como é o caso, as idéias são interessantes para a leitura que proponho do romance de Diogo Mainardi. Em 
outras palavras, o mesmo "movimento" que Sant'Anna explicita nos poetas modernistas, pode ser detectado na ficção em causa:

[...] na paródia o texto histórico deslocado soa estranhamente. É exatamente o efeito de estranhamento que se consegue fazendo a palavra aparecer fora de seu lugar natural. Oswald de Andrade montou muitos de seus poemas com frases extraídas dos viajantes e descobridores. A seleção e a combinação dessas sentenças é que resultam no efeito paródico [...].

Das linguagens do Modernismo a paródia tem sido a única claramente referida pela crítica até hoje. Falta agora relacioná-la não apenas com as outras linguagens, mas destacar que ela não é específica de um ou outro autor. Ela é antes um solo comum a todos.

(SANT'ANNA, 1975, p. 63-64)

Note-se que o resultado obtido por Diogo Mainardi não é mais uma novidade. Não se trata, efetivamente, de uma criação original, a considerar o que diz Affonso Romano de Sant'Anna. O estranhamento no texto do romance é o mesmo sentido e detectado pelo crítico, quando de sua análise da poesia modernista. Por outro lado, o lugar "natural" das citações no texto do romance aparece também deslocado. Exatamente como Oswald de Andrade já praticava em sua poesia. Por fim, quando se trata de "anunciar" a boa nova da nacionalidade antropofagicamente constituída, os modernistas - e, em certo sentido, pode-se arrolar o nome de Diogo Mainardi nessa lista - são unânimes em eleger a paródia como uma linguagem “comum”, o que confirma essa mesma hipótese. Por essas e por outras, a consideração de Contra a nação como uma narrativa que privilegia a paródia, seria reduzir muito a sua leitura, fazendo com que o texto fosse limitado a uma conjunção ideológica com a estética modernista: isso é apenas perceber e anotar o óbvio.

O romance trata basicamente da história de Pimenta Bueno que, depois de incendiar um prédio velho no centro de São Paulo, matando supostamente um grupo de mendigos que ali se alojara, sai numa busca desenfreada da redescoberta da trilha feita pelo Marechal Rondon, quando da implantação de uma linha telegráfica. As peripécias do protagonista se desenrolam em plena selva brasileira, o que não poderia deixar de acontecer! Os nambiquara são seu objeto de desejo, num afã de refazer o contato primitivo e rever toda a visão do Brasil, principalmente aquela marcada pela obra de Lévi-Strauss: eminência parda de todo o relato. Ao final, o protagonista volta a São Paulo e de lá parte para a Europa, quando reencontra Luísa, a índia com quem manteve relação prolongada, quando esteve na selva. Ela tem um filho e os dois voltam a se encontrar, não sem uma certa relutância de Pimenta Bueno que “prepara-se para ir embora. Antes disso, porém, abre a bolsa de Luísa e rouba os poucos trocados que encontra em sua carteira. depois parte assoviando o Estudo número 3, opus 10, de Chopin. (Mainardi, 1998, 214) 
A referência a Chopin se deve, é claro, a Lévi-Strauss que, segundo o protagonista e o próprio narrador, teria assoviado muitas vezes trechos dessa peça romântica, para afugentar o tédio e uma certa irritação que sentia quando de sua visita ao Brasil em 1939. Percebe-se assim, antropofagicamente, a anarquização - quase carnavalesca, para lembrar Bakhtin -, do discurso do antropólogo: uma outra paródia que tem início, como já referido, na própria capa da edição compulsada. Instaura-se, então, uma certa ambigüidade, a marcar todo o desenvolvimento do relato ficcional: um posicionamento contra a pátria, como quer o título da obra, é construído pelo olhar "estrangeiro", a favor de uma pátria mais "natural". Essa peculiaridade estaria respaldada pela revalorização dos Nambiquara: exemplo ficcional da "geração original” do Brasil, na perspectiva do próprio Romantismo. A estrutura da narrativa, montada em diálogos, evidencia uma perspectiva praticamente cinematográfica, o que privilegia a dicção dialógica do relato do próprio Pimenta Bueno, a partir das citações que vai vociferando mata adentro, Brasil afora. Gostaria de destacar dois trechos do romance para a brevíssima consideração anunciada no início. O primeiro deles faz uma referência direta a Rudyard Kipling:

PIMENTA BUENO Rudyard Kipling jamais se recuperou dos infortúnios poéticos em terras brasileiras! É necessário dividir sua obra entre antes e depois da vinda ao Brasil!

Pimenta Bueno dobra o corpo para a frente e, com a cabeça em riste, parte a toda velocidade rumo ao cupinzeiro.

PIMENTA BUENO Por mais talentosos que sejam, todos os estrangeiros que vêm ao Brasil passam por esse irreversível processo de atrofia intelectual!

Pimenta Bueno acelera cada vez mais.

PIMENTA BUENO o Brasil tem o poder de dissipar as inteligências!

É iminente o impacto com o cupinzeiro. (MAINARDI, 1998, p. 81)

O caráter fortuito da referência ao poeta inglês serve apenas de "deixa" para uma estocada ferina no posicionamento naturalista de Sílvio Romero. Trata-se da famosa “obnubilação Brasília” que, nas palavras do crítico e historiador brasileiro, é um fenômeno que afeta todos os estrangeiros que aqui aportam, fazendo com que vejam o Brasil com olhos exaltados. A exuberância da flora, a liberalidade de costumes, o clima tropical e o exotismo causado pela distância, inauguram uma alteridade sedutora que reveste o Brasil e faz com que seja visto de maneira distorcida. Implicitamente, o que o relato ficcional de Mainardi demonstra é que posicionamentos como esses, de brasileiros e/ou estrangeiros, contribuíram, e muito, para a distorção de uma auto-imagem possível. A ficção, nesse caso, tenta resgatar o que está encoberto por esses discursos cruzados, ainda que esse exercício esteja sendo feito 
por alguém que está "fora" de seu próprio território. Distância cômoda e ambígua, ao mesmo tempo; eficaz e perigosa, pois coloca seu "locutor" numa posição de mesmo quilate: ao mesmo tempo em que critica, defende; simultaneamente à desconstrução discursiva, reafirma uma auto-imagem,construída pelo avesso. O segundo trecho que desejo destacar faz uma referência direta a Gonçalves Dias. É o seguinte:

PIMENTA BUENO Gonçalves Dias descreveu esse momento em "Leito de folhas verdes", em que uma jovem índia prepara o terreno à espera do amante: "Eu sob a copa da mangueira altiva / Nosso leito gentil cobri zelosa / Com mimoso tapiz de folhas brandas".

LUÍSA Gonçalves Dias? Quem é Gonçalves Dias?

PIMENTA BUENO "O maior poeta do Brasil, aquele que com mais ardente lirismo cantou a majestade da terra brasileira, a nobreza,o valor e o infortúnio da raça selvagem”, segundo Olavo Bilac.

LUÍSA Eu não gosto de poesia. Prefiro cuspir na cara dos outros.

(MAINARDI, 1998, p. 115)

Nesta passagem, o protagonista está prestes a manter uma relação sexual com uma índia Nambiquara em troca de anzóis e/ou outras prendas. O detalhe é que Luísa é mulher de José Maria, outro índio, a quem Pimenta Bueno convence de que a cessão de sua esposa a um branco era prática socialmente adequada e aproximativa de sua tribo. Na sintonia de minha apresentação, a passagem ressalta a verve irônica de Pimenta Bueno, que, desta feita, volta-se para um dos epígonos do romantismo indianista da Literatura Brasileira. Como Santa Rita Durão, outro poeta citado pelo protagonista, Gonçalves Dias é, da mesma maneira ambígua que na passagem anterior, relido pelo protagonista. Ao tentar cometer um ato condenável, numa certa perspectiva moral, Pimenta Bueno respalda-se num epígono da mitologia literária brasileira, para justificar esse mesmo ato. O "leito de folhas verdes" é o espaço em que a "nova" visão da brasilidade terá que ser vista, depois que Luísa cai na lábia de Pimenta Bueno. O uso inveterado do poeta romântico evidencia o espírito antropofágico que marca a ficção de Diogo Mainardi. Deglutindo não apenas as referências estrangeiras, mas regurgitando as nacionais, o protagonista vai reacendendo a chama de uma discussão que parecia concluída depois da Semana de 22, principalmente depois do mapeamento feito pelo Regionalismo, nos anos 30. O que aqui já foi exposto leva-me a pensar numa passagem do famoso ensaio de Roberto Schwarz, “As idéias fora do lugar”, que passo a citar:

Ao longo de sua reprodução social, incansavelmente, o Brasil põe e repõe idéias européias, sempre em sentido impróprio. É nesta qualidade que elas são matéria e problema para a literatura. $\mathrm{O}$ escritor pode não saber disso, nem precisa, para usá-las. Mas só alcança uma ressonância profunda e afinada caso lhes sinta, registre e desdobre - ou evite - o descentramento e a desafinação. Se há um número indefinido de maneiras de fazê-lo, são palpáveis e definíveis as contravenções. Nestas registra-se, como ingenuidade, tagarelice, 
estreiteza, servilismo, grosseria, etc., a eficácia específica e local de uma alienação de braços longos - a falta de transparência social, imposta pelo nexo colonial e pela dependência que veio continuá-lo. (SCHWARZ, 1981, p. 24)

Tratando especificamente da obra de Machado de Assis, a passagem aqui citada não deixa de referendar o que venho dizendo sobre o romance de Diogo Mainardi em apreço. As "idéias fora do lugar" de que trata o ensaio, em sua particular visada sobre o século XIX literário no Brasil, são, em certa medida, as mesmas que o protagonista de Contra a nação utiliza em sua perplexa e peripatética caminhada pelo "interior" do Brasil. O adjetivo “interior”, aqui, corrobora a ambigüidade da ficção de Mainardi, uma vez que ele fala de fora do Brasil, com os olhos dos estrangeiros - suas citações - sem, no entanto, deixar de "botar o dedo na ferida". É o mesmo movimento de que trata o ensaio de Schwarz, com um resultado diferenciado.

A impropriedade de que trata o ensaísta, não "cabe" na ficção de Mainardi, uma vez que a desconstrução é a marca de sua dicção ficcional: prática respaldada no ideário modernista, posterior ao período recortado pelo ensaísta. Por outro lado, a desafinação e o descentramento, que lá são características desabonadoras, aqui, tornam-se pontos de amarração do próprio discurso antropofágico do protagonista. Contra a nação é uma das "palpáveis e definíveis" contravenções de que fala o ensaísta. Nesta, a marca dialógica dos diversos pontos de vista, conjugados na atabalhoada saga de Pimenta Bueno, revela um cuidado inusitado em cercar esses mesmos pontos de vista, numa conjugação outra, mais perversa, menos comprometida com ideários estéticos e/ou sócio-políticos. A contravenção não pode ser punida, mas saldada como uma tentativa, no mínimo, interessante de resgatar um senso crítico um tanto embotado pelas rocambolescas investidas do que se convencionou chamar de "pós-modernidade". Em terras coloniais, fica um tanto difícil se livrar da influência falaciosa de discursos aparentemente redentores.

Numa digressão final, fico pensando se a ficção de Mainardi também não abre espaço para a discussão de uma dicotomia questionável: moderno versus pós-moderno. Esta possibilidade a meu ver, necessita sempre de cuidado redobrado, sob pena de tomar como legítimas as constatações de um sujeito leitor, no afã de dar vazão a seu próprio pensamento. Explico-me. O que há por detrás das discussões filosóficas, nem sempre é apreendido por todos os leitores. Assim sendo, este tipo de digressão, muito mais que criar um problema para o leitor "desavidado", abre para elas portas inusitadas, em que seu próprio exercício de leitura ganha status de elucubração filosófica. 
O paradigma cultural da Modernidade se constituiu antes do modo de produção capitalista ter se tornado dominante e extinguir-se-á antes de este último deixar de ser dominante. O paradigma cultural da Modernidade constituiu-se entre o século XVI e finais do século XVIII coincidindo, aproximadamente, com a emergência do capitalismo enquanto modo de produção dominante nos países da Europa. Podem-se distinguir três períodos neste processo. O primeiro, cobrindo todo o século XIX, o período do capitalismo liberal. O segundo vai do fim do século XIX até o período após a Segunda Guerra Mundial, caracterizado pelo capitalismo organizado. O terceiro é o que se inicia no final da década de sessenta, quando se observa um crescimento de efeito do capitalismo financeiro, também designado de capitalismo desorganizado, sobre todas as possibilidades de criação cultural bem como da crítica que a esta produção poderia ser feita.

Por ser um projeto muito rico, a Modernidade é capaz, inclusive, de movimentos contraditórios e complexos que podem ser compreendidos a partir da interação de dois princípios gerais: o da regulação e o da emancipação. Cada um desses pilares, por sua vez, também é constituído pela articulação de três outros princípios secundários que se relacionam entre si. O pilar da regulação é constituído pelos princípios do Estado, do mercado e da comunidade. Por sua vez, o pilar da emancipação seria formado por três lógicas de racionalidade: a racionalidade estético-expressiva da arte e da literatura; a racionalidade moral-prática da ética e do direito; e a racionalidade cognitivo-instrumental da ciência e da técnica.

A racionalidade estético-expressiva articula-se, privilegiadamente, com o princípio da comunidade, onde se condensam as idéias de identidade e comunhão, intimamente relacionados à contemplação estética. Já a racionalidade moral-prática conecta-se, preferencialmente, ao princípio do Estado, e a racionalidade cognitivo-instrumental corresponde-se ao princípio do mercado; tanto porque nele se condensam idéias de individualidade e concorrência - centrais ao desenvolvimento da técnica - como pela conversão da ciência numa força produtiva a partir do século XVIII.

A partir da articulação desses princípios entre si, e da proposta de maximização das potencialidades inerentes a cada um deles, a Modernidade construiu um ambicioso e revolucionário projeto cultural, que buscou transformar a face da Terra pela fé na ciência e na técnica aplicadas às forças produtivas; nas relações liberais de mercado como capazes de implementar um Estado justo e próspero; na positividade do progresso e na sua constante renovação e superação. No entanto, o que se observou é que, ao invés dos princípios coexistirem harmoniosamente, sinergicamente, eles se sobrepuseram uns aos outros, levando 
o processo a um desequilíbrio. Por exemplo, no período do capitalismo liberal, houve um desenvolvimento sem precedentes do princípio do mercado, atrofiando o princípio da comunidade e pressionando o estado a uma re-significação de seu papel.

Assim, o princípio de comunidade, baseado na igualdade entre os sujeitos e na organização soberana da sociedade, reduziu-se a um complexo jogo de interesses particulares organizados dentro de um conceito empobrecido de sociedade civil, manipulado pelas forças de mercado. No domínio do princípio da emancipação, observou-se, por exemplo, a elitização da cultura, conjugada à idéia da existência e valorização de uma cultura nacional. Também houve a conversão da ciência numa força produtiva estreitamente vinculada e a serviço do mercado. Por fim, pode ser percebida a exacerbação do individualismo competitivo, denegando as articulações dialógicas (sempre) possíveis.

Já no âmbito da racionalidade moral e prática, consolidou-se a micro-ética liberal que contribuiu para a legitimação de um Estado a serviço do mercado. Assim, os vários princípios interagindo entre si não foram capazes de cumprir com as propostas modernas que visavam, entre outros objetivos, a prosperidade social a partir do desenvolvimento da técnica, da ciência aplicada e do livre mercado. Se por um lado a ciência e a técnica avançaram, talvez, além do esperado, a contrapartida de prosperidade social e cultural não se concretizou. Avaliar se esses objetivos ainda são pertinentes e se a Modernidade ainda tem condições de cumpri-los é uma tarefa árdua que necessita ser feita, para que se possa compreender a existência, configuração e, mesmo necessidade, de um novo paradigma dito pós-moderno.

Para avaliar se há a exaustão do paradigma moderno e o surgimento de um novo paradigma, cumpre ainda observar quais são os pressupostos e fundamentos filosóficos da Modernidade e em que medida estes se encontram transformados, alterados no contexto de uma nova articulação da realidade, uma pós-Modernidade. A Modernidade, como pensa muita gente, caracteriza-se, de fato, por ser dominada pela idéia da História do pensamento como uma iluminação progressiva, que se desenvolve com base na apropriação e na re-apropriação cada vez mais plena dos fundamentos, que freqüentemente são pensados também como as origens, de modo que as revoluções teóricas e práticas da história ocidental se apresentam e se legitimam na maioria das vezes como recuperações, renascimentos, retornos. É a partir da noção de "superação" que a Modernidade legitima este desenvolvimento, esta iluminação progressiva do pensamento, que se re-apropria e re-significa o seu próprio fundamento e origem.

A Modernidade também se caracteriza por ser a época da História em oposição à visão naturalista e cíclica do curso do mundo, fato que pode ser entendido a partir do processo de 
secularização e de autonomização do pensamento, nos domínios da ciência e da técnica. Desta forma, a pós-Modernidade só pode ser compreendida como uma instância legítima, na medida em que oferecer respostas originais para os três fundamentos filosóficos da Modernidade: as noções de progresso, história e superação. A pura e simples consciência - ou pretensão - de representar uma novidade na história, uma figura nova e diferente na fenomenologia do espírito, colocaria de fato o pós-moderno na linha da Modernidade.

Por isso, o pós-moderno deve se caracterizar não por se tratar de uma novidade, mas sim por trazer uma dissolução na categoria do novo; e também, como uma experiência de fim da História, onde a idéia de um processo histórico unitário se dissolve. Neste processo, a História dos eventos, a História dos vencedores, se torna apenas uma história entre outras incluem-se aqui a miríades de viajantes, cientistas e "curiosos" que passaram pelo Brasil ao longo de sua História, e sobre este país afirmaram suas próprias "verdades", como jocosamente parodiado por Diogo Mainardi. Paradoxalmente, vive-se uma época em que os mecanismos de coleta e troca de informações podem até permitir a realização de uma história universal. No entanto, a realização desta História tornou-se impossível. O nivelamento da experiência no plano da simultaneidade e da contemporaneidade produziu uma deshistoricização da experiência.

Este contexto tem se desenvolvido à medida que o progresso se tornou uma rotina. Quanto mais aumentam as possibilidades do sujeito de dispor tecnicamente da natureza, de alcançar novos resultados, menos novos esses resultados se tornam, por se basearem em uma lógica esvaída. Um processo de exaustão e, onde a novidade é cada vez menos nova, menos revolucionária, permitindo apenas que as coisas prossigam do mesmo modo. Tendo sido suprimido o "para onde" do conhecimento, no processo de secularização do pensamento, a noção de progresso tornou-se vazia, tautológica, cujo único ideal final é a realização das condições para um progresso subseqüente.

Se à primeira vista a técnica se apresenta como uma ameaça à metafísica, ao humanismo, à subjetividade, numa análise mais profunda percebe-se que, em sua essência, em sua lógica neste século, ela representa o desdobramento máximo da metafísica. Ela é um dos elos do processo da afirmação do homem como ser cognoscível e soberano. Paradoxalmente, à medida que o sujeito se afirma como Ser, a partir da verdade da técnica, ele perde, paralelamente, a força da sua subjetividade, objetivizando-se como uma peça, um dado de uma lógica imanente, superior. Desta forma, depreende-se que a essência da técnica não é algo técnico e, sim, metafísico, uma etapa pertinente do projeto humanista de Modernidade. A 
universalização do domínio da informação, por exemplo, pode ser interpretada como uma realização pervertida do espírito absoluto.

Nesse ínterim, o valor do Ser foi reduzido a um valor de troca. É a consumação da morte de Deus, nos termos de Nietzsche, e a instauração do tempo do niilismo: a liquidação dos valores supremos não gera uma situação de valor num sentindo forte, nem tampouco cria uma experiência mais autêntica que a anterior. Se, ao mesmo tempo, o niilismo estabelece o confronto com as incertezas de abandonar o Ser como fundamento, também convida para um salto em seu abismo. Sair da rigidez do imaginário, do estabelecimento unívoco de novos valores supremos e empreender uma jornada na mobilidade do simbólico.

No entanto, chega um momento em que a vanguarda (o moderno) não pode ir mais além porque já produziu uma metalinguagem que fala de seus textos impossíveis. A resposta pós-moderna ao moderno consiste em reconhecer que o passado, já que não pode ser destruído porque sua destruição leva ao silêncio, deve ser revisitado: com ironia, de maneira não inocente. No entanto, para que a pós-Modernidade em seu caráter niilista possa realizarse, o sujeito deve ser repensado à luz de um modelo não-positivista, não-metafísico. Para tanto, a experiência da arte apresenta-se como um modelo possível a qual deve ser compreendida, não como uma passagem da experiência do verdadeiro ao domínio do senso comum - relativista, intimista -, mas como um campo que tem uma complexidade de sentidos que não se limita a duplicar o existente, capaz inclusive de criticá-lo, re-significá-lo. Essa transformação passa pela consideração da verdade, não como objeto de que se pode tomar posse e transmitimos, mas como horizonte e pano de fundo no qual, discretamente, o sujeito pode se mover: passa pela incerteza, pelo acaso, pela descontinuidade, pelo caos, pela complexidade. Se não há respostas mágicas para as contradições da existência, estas estão em movimento, e esse movimento pode criar respostas, também em movimento. Julgo, entretanto, que o pós-moderno não é uma tendência que possa ser delimitada cronologicamente, mas uma categoria espiritual, melhor dizendo, um modo de operar.

Se estas idéias não podem ser direta e explicitamente articuladas à leitura do romance de Diogo Mainardi, elas têm a propriedade de expandir o horizonte de expectativas da leitura do próprio texto. Nesse sentido, a personagem central de Contra a nação pode ser lida como o porta-voz de um discurso sub-liminar que a própria leitura do texto de Mainardi oferece aos olhos ávidos de um leitor que se vê, de repente, imerso num emaranhado de citações e referências. Pimenta Bueno é um sujeito que pode ser apreendido sob o enfoque das duas perspectivas: a moderna e a pós-moderna, a considerar as elucubrações desta minha digressão final. 
Ao final, o que se pode dizer é que uma certa verdade, vista de fora, é revelada. Pimenta Bueno é um nacionalista ao contrário. Na contra-mão de uma certa xenofobia, o narrador afirma, pela denegação, o sentimento quase nostálgico de uma recuperação impossível: a visão paradisíaca do Brasil. O mito do indianismo e da exuberância da flora cai por "terra", no discurso arrevesado de um idealista fracassado. Se Nietzsche tiver razão, desse fracasso fica uma lição insofismável: a impossibilidade de negar o que se vê. Como na epígrafe de Montaigne, caiu a máscara de um Brasil romantizado pelo olhar estrangeiro. Foi preciso o confronto de um brasileiro, fora de lugar, como as insuspeitadas idéias que Roberto Schwarz tanto e tão claramente explicitou, para deixar cair a máscara de um nacionalismo tacanho. Assim, num confronto dialógico, instigante e irônico, revela-se o homem, metáfora do Brasil...

\section{Referências}

COMPAGNON, Antoine. O demônio da teoria: literatura e senso comum. Belo Horizonte: Ed.UFMG, 1999.

ISER, Wolfgang. The implied reader: patterns of communication in prose fiction from Bunyan to Beckett. London: Baltimore: The Johns Hopkins University Press, 1978

MAINARDI, Diogo. Contra o Brasil. São Paulo: Companhia das Letras, 1998.

MARTIN, Wallace. Recent theories of narrative. London: Ithaca: Cornell University Press, 1987

MOREIRAS, Alberto. A exaustão da diferença: a política dos estudos culturais latinoamericanos. Belo Horizonte: Ed.UFMG, 2001.

ROCHA, João Cezar de Castro (org.). Teoria da ficção: indagações à obra de Wolfgang Iser. Rio de Janeiro: Ed.UERJ, 1999.

SANT'ANNA, Affonso Romano de. Modernismo: as poéticas do centramento e do descentramento. In; ÁVILA, Affonso (org.). O modernismo. São Paulo: Perspectiva: Secretaria da Cultura, Ciências e Tecnologia do Estado de São Paulo, 1975. Coleção Stylus, 1.

SCHWARZ, Roberto. Ao vencedor as batatas: forma literária e processo social nos inícios do romance brasileiro. 2 ed. São Paulo: Duas cidades, 1981. 